\title{
Analisis Perilaku Penumpang KRL Commuter Line Solo Balapan - Yogyakarta di Masa Pandemi dan Pengaruhnya terhadap Pola Perjalanan
}

\author{
Tri Safira Indriani ${ }^{1)}$, Sodikin $^{2)}$, Tantin Pristyawati ${ }^{3)}$ \\ 1) Fakultas Teknik, Program Studi Teknik Sipil, Universitas Veteran Bangun Nusantara, Sukoharjo, Jl. Letjen \\ Sudjono Humardhani, No.1, Jombor, Sukoharjo; Telp. 0271-593156. Email: trisafiraindriyani@ gmail.com \\ ${ }^{2)}$ Fakultas Fakultas Teknik, Program Studi Teknik Sipil, Universitas Veteran Bangun Nusantara, Sukoharjo, Jl. \\ Letjen Sudjono Humardhani, No.1, Jombor, Sukoharjo; Telp. 0271-593156. Email: \\ sodikinusman2012@gmail.com \\ ${ }^{3)}$ Fakultas Fakultas Teknik, Program Studi Teknik Sipil, Universitas Veteran Bangun Nusantara, Sukoharjo, Jl. \\ Letjen Sudjono Humardhani, No.1, Jombor, Sukoharjo; Telp. 0271-593156. Email: \\ tantinsipil@univetbantara.ac.id
}

\begin{abstract}
Abstrak
KRL Commuter Line merupakan transportasi pilihan yang ramai diminati oleh masyarakat kota Solo Balapan Yogyakarta sejak beroperasi Februari 2021. Beroperasinya KRL ditengah masa pandemi ini membuat pihak PT KAI menetapkan kebijakan yang lebih ketat dalam menerapkan protokol kesehatan guna memutus mata rantai penyebaran covid-19. Penelitian ini dilakukan untuk mengetahui pengaruh perilaku penumpang terhadap pola perjalanan serta mengetahui pengaruh kebijakan yang direalisasikan oleh petugas operator KRL pada pola perjalanan. Teknik pengambilan data menggunakan kuesioner yang dibagikan secara online, kemudian diolah menggunakan Microsoft Excel dan SPSS (Statistical Product and Service Solution). Teknik analisis yang digunakan adalah analisis regresi linear berganda. Hasil penelitian secara parsial menunjukkan bahwa $t$ hitung $(1,280)<\mathrm{t}$ tabel $(1,985)$, sehingga $\mathrm{H} 1$ ditolak atau tidak berpengaruh terhadap pola perjalanan. Sedangkan secara simultan menunjukkan bahwa variabel perilaku penumpang (X1) dan pandemi (X2) berpengaruh terhadap pola perjalanan penumpang KRL (Y) secara simultan sebesar 0,000 yang artinya sig < 0,05 . Dan nilai $\mathrm{f}$ hitung $(17,787)$ $>\mathrm{f}$ tabel $(3,09)$. Yang artinya apabila kebijakan yang direalisasikan optimal serta penumpang mematuhi kebijakan tersebut maka keamanan dan kenyamanan yang dirasakan penumpang juga akan maksimal. Persentase pengaruh kedua variabel tersebut sebesar $25,1 \%$ yang dihitung melalui uji koefisien determinasi.
\end{abstract}

Kata kunci : KRL Commuter Line, pandemi, perilaku penumpang, pola perjalanan.

\begin{abstract}
The Commuter Line KRL is the preferred transportation that has been in high demand by the people of the Solo Balapan - Yogyakarta city since operating in February 2021. The operation of the KRL in the midst of this pandemic has forced PT KAI to set stricter policies in implementing health protocols to break the chain of the spread of COVID-19. This study was conducted to determine the effect of passenger behavior on travel patterns and to determine the effect of policies realized by KRL operator officers on travel patterns. The data collection technique used a questionnaire that was distributed online, then processed using Microsoft Excel and SPSS (Statistical Product and Service Solution). The analysis technique used is multiple linear regression analysis. The results of the study partially show that t count (1.280) < t table (1.985), so Hl is rejected or has no effect on travel patterns. Meanwhile, simultaneously, it shows that the variable of passenger behavior (X1) and pandemic (X2) affects the travel pattern of KRL passengers $(Y)$ simultaneously by 0.000 , which means sig $<0.05$. And the calculated $f$ value (17.787) $>$ f table (3.09). This means that if the policies are implemented optimally and passengers comply with these policies, the security and comfort felt by passengers will also be maximized. The percentage of the influence of the two variables is $25.1 \%$ which is calculated through the coefficient of determination test.
\end{abstract}

Keywords: Commuter Line KRL, pandemic, passenger behavior, travel patterns. 


\section{PENDAHULUAN}

Pada era globalisasi ini sarana transportasi juga semakin modern, sehingga manusia dapat memilih transportasi mana yang paling ideal dan efektif untuk dirinya sendiri. Salah satunya adalah KRL (Kereta Rel Listrik). PT. KCI (Kereta Commuter Indonesia) merupakan anak perusahaan yang mengelola KRL, dibentuknya anak perusahaan ini bertujuan memberikan pelayanan yang berkualitas dan menjadi bagian dari solusi masalah transportasi perkotaan yang semakin kompleks. Untuk memenuhi permintaan penumpang yang terus bertambah dari waktu ke waktu, saat ini KCI melayani kurang lebih 80 stasiun di Indonesia termasuk stasiun Solo Balapan -Stasiun Yogyakarta. KRL Solo - Yogyakarta beroperasi sejak 10 Februari 2021 dan jumlah penumpang sampai tanggal 14 Februari mencapai 24 ribu penumpang. KRL pertama yang berada diluar jabodetabek ini beropersi ditengah pandemi, sehingga membuat pihak instansi terkait memberlakukan kebijakan kepada penumpang maupun petugas terkait protokol kesehatan guna memutus mata rantai penyebaran covid 19.

Pada 2 Maret 2020 Indonesia dikejutkan dengan kasus terkonfirmasi positif virus Covid-19. Hal itu menyebabkan pemerintah Indonesia menyatakan keadaan darurat bencana akibat penyebaran virus yang semakin meningkat maka pemerintah menetapkan kebijakan untuk melakukan gerakan Social Distancing.

Penelitian ini bertujuan untuk mengidentifikasi perilaku penumpang dalam menerapkan regulasi yang berlaku di KRL serta persepsi penumpang terhadap kebijakan yang diterapkan operator moda jasa transportasi PT.KCI serta pengaruhnya terhadap pola perjalanan yang ditinjau dari keamanan dan kenyamanan penumpang.

\section{Pengertian Perilaku}

Perilaku secara rasional dapat diartikan sebagai respon seseorang terhadap rangsangan dari luar subyek tersebut. Respon ini terbentuk dua macam yakni pasif dan aktif dimana bentuk pasif merupakan respon internal yang terjadi dalam diri manusia sedangkan bentuk aktif merupakan respon yang dapat dilihat secara langsung dimana perilaku dapat diobservasi secara langsung (Triwibowo, 2015).

\section{Pola Perjalanan Manusia}

Faktor yang mempengaruhi pola perjalanan individu berupa faktor internal yaitu sosial ekonomi (biaya, efisiensi, waktu) dan faktor eksternal yaitu kondisi lalu lintas (keamanan, kenyamanan, jarak). (Khisty,1998)

\section{Pandemi Virus Covid-19 di Indonesia}

Indonesia merupakan salah satu negara yang menjadi bagian dari pandemi penyakit korona virus 2019 (Covid 19) yang telah ditetapkan WHO (World Health Organization). Berdasarkan data Gugus Tugas Covid-19 Republik Indonesia per tanggal 31 Juli 2021 Indonesia melaporkan 3.370.000 kasus positif, pasien sembuh 2.730 .000 , dan pasien meninggal 92.311 karena terpapar Covid-19. Masih banyaknya masyarakat yang tidak mengikuti imbauan dari pemerintah, menyebabkan penyebaran virus ini semakin cepat.

\section{Definisi Operasional}

Tabel 1 Indikator Operasional dan Variabel

\begin{tabular}{|c|c|c|c|}
\hline No. & $\begin{array}{l}\text { Variabel } \\
\text { Penelitian }\end{array}$ & $\begin{array}{c}\text { Definisi } \\
\text { Operasional }\end{array}$ & Indikator \\
\hline 1. & $\begin{array}{l}\text { Perilaku } \\
\text { Penumpang } \\
\text { (X1) }\end{array}$ & $\begin{array}{l}\text { Kesadaran } \\
\text { penumpang } \\
\text { dalam } \\
\text { menerapkan } \\
\text { protokol } \\
\text { kesehatan }\end{array}$ & $\begin{array}{l}\text { Kotler } \\
(\mathbf{2 0 0 1 )} \text { : } \\
\text { - Faktor } \\
\text { pribadi } \\
\text { - Psikologi }\end{array}$ \\
\hline 2. & $\begin{array}{l}\text { Masa } \\
\text { pandemi } \\
(\mathrm{X} 2)\end{array}$ & $\begin{array}{l}\text { Acuan pada } \\
\text { variabel masa } \\
\text { pandemi ini } \\
\text { adalah } \\
\text { kebijakan } \\
\text { yang } \\
\text { diberlakukan } \\
\text { oleh PT KCI. } \\
\text { Terealisasinya } \\
\text { kebijakan } \\
\text { dinilai } \\
\text { berdasarkan } \\
\text { persepsi } \\
\text { penumpang }\end{array}$ & $\begin{array}{l}\text { Budimanta } \\
\text { (2020) } \\
\text { - Ketersedi } \\
\text { aan alat }\end{array}$ \\
\hline 3. & $\begin{array}{l}\text { Pola } \\
\text { perjalanan } \\
(\mathrm{Y})\end{array}$ & $\begin{array}{l}\text { Pola } \\
\text { perjalanan } \\
\text { pada } \\
\text { penelitian ini } \\
\text { berupa } \\
\text { keamanan dan } \\
\text { kenyamanan } \\
\text { penumpang } \\
\text { yang pernah } \\
\text { menggunakan } \\
\text { KRL Solo - } \\
\text { Jogja di masa } \\
\text { pandemi. }\end{array}$ & $\begin{array}{l}\text { Khisty } \\
\text { (1998) : } \\
\text { - Internal } \\
\text { - Eksternal }\end{array}$ \\
\hline
\end{tabular}

\section{METODE}


Penelitian ini merupakan penelitian deskriptif yang didukung dengan data kuantitatif. Pengambilan data diperoleh dari survey online yang diakses melalui google formulir kemudian dibagikan kepada masyarakat yang pernah menggunakan KRL sepanjang jalur lintas Solo - Yogyakarta. Teknik penentuan sampel yang digunakan adalah metode non probability sampling jenis purposive sampling dengan jumlah minimal 50 responden. Namun jumlah 50 responden dirasa kurang dalam mempresentasikan populasi, maka peneliti menentukan jumlah minimal responden sebanyak 120 reponden.

\section{Metodologi Penelitian}

Sebelum survey, yang harus dilakukan terlebih dahulu adalah plot survey untuk mengetahui kondisi lapangan dan menguji kelayakan kuesioner. Sumber data yang digunakan dalam penelitian ini antara lain data primer dan data sekunder. Data primer diperoleh dari hasil kuesioner yang disebar oleh peneliti, sedangkan data sekunder diperoleh dari sumber yang telah ada.

Pengolahan data menggunakan analisa tabulasi dan variabel-variabel diuji dengan uji korelasi, kemudian dilakukan analisa faktor untuk menyatukan variabel yang memiliki hubungan yang sama. Pengujian instrument dilakukan supaya mengetahui penelitian ini berguna atau tidak. Uji instrument tersebut berupa uji validasi dan reliabilitas. Validasi berhubungan dengan benar tidaknya data yang diteliti. Reliabilitas berhubungan dapat digunakan atau tidaknya data tersebut. Dalam penelitian ini metode analisis yang digunakan adalah analisis regresi linear berganda. sebagai alat hitung karena dalam penelitian ini terdapat satu variabel dependen yaitu pola perjalanan dan dua variabel independen yaitu perilaku penumpang dan masa pandemi. Pengujian yang dilakukan menggunakan Microsoft Excel dan SPSS (Statistical Product and Service Solutions).

Tahap terakhir yaitu menarik kesimpulan dari penelitian yang telah dilakukan, berupa tindakan penumpang dalam menerapkan protokol kesehatan serta persepsi penumpang menilai petugas operator dalam menerapkan kebijakan yang diberlakukan di dalam KRL.
Gambar 1 Diagram Alir Penelitian

\section{HASIL DAN PEMBAHASAN}

Penyebaran kuesioner mulai dilakukan pada tanggal 18 Juni sampai 2 Juli 2021 secara daring (dalam jaringan). Kuesioner ini berisikan 24 butir pernyataan diukur dengan skala likert, kuesioner dibagikan melalui link google formulir. Dari hasil perhitungan jumlah minimum sampel yang diperoleh 50 responden kemudian dilebihkan menjadi 120 kuesioner guna mengantisipasi kuesioner yang tidak lengkap. Kemudian dari 120 kuesioner yang terkumpul ada 109 kuesioner yang lengkap dan layak diolah.

\section{Diagram Penelitian}




\section{Karakteristik Responden}

Tabel 2 Distribusi Karakteristik Responden Sumber : Hasil olah data primer, 2021

\begin{tabular}{|c|c|c|}
\hline Karakteristik & Jumlah & Presentase \\
\hline \multicolumn{3}{|c|}{ Jenis Kelamin } \\
\hline Laki-laki & 58 & $53,21 \%$ \\
\hline Perempuan & 51 & $46,79 \%$ \\
\hline Total & 109 & $100 \%$ \\
\hline \multicolumn{3}{|c|}{ Usia } \\
\hline$<17$ tahun & 14 & $12,84 \%$ \\
\hline $17-40$ tahun & 85 & $77,98 \%$ \\
\hline $41-60$ tahun & 10 & $9,17 \%$ \\
\hline$>60$ tahun & 0 & $0 \%$ \\
\hline Total & 109 & $100 \%$ \\
\hline \multicolumn{3}{|c|}{$\begin{array}{c}\text { Frekuensi menggunakan KRL seminggu } \\
\text { (PP) }\end{array}$} \\
\hline $1-3$ kali & 97 & $88,99 \%$ \\
\hline $4-6$ kali & 11 & $10,09 \%$ \\
\hline$>6$ kali & 1 & $0,92 \%$ \\
\hline Total & 109 & $100 \%$ \\
\hline \multicolumn{3}{|c|}{ Tujuan perjalanan } \\
\hline Bekerja & 38 & $34,86 \%$ \\
\hline Sekolah / Kuliah & 8 & $7,34 \%$ \\
\hline Rekreasi & 50 & $45,87 \%$ \\
\hline $\begin{array}{l}\text { Kunjungan } \\
\text { keluarga }\end{array}$ & 13 & $11,93 \%$ \\
\hline Total & 109 & $100 \%$ \\
\hline
\end{tabular}

\section{A. Uji Instrumen}

\section{Uji Validitas}

Pengujian dilakukan dengan membandingkan nilai r-hitung dengan nilai r-tabel. Jika r-hitung untuk $r$ tiap item pertanyaan bernilai positif kemudian lebih besar dari r-tabel maka item pertanyaan hasilnya valid, sebaliknya jika r-hitung kurang dari r-tabel maka item pertanyaan tidak valid. Dalam penelitian ini uji validitas menggunakan teknik korelasi melalui koefisien korelasi product moment dari rumus Pearson.

\section{Uji Reliabelitas}

Uji reliabilitas ini dilakukan setelah uji validitas, yang mana data yang diukur harus valid dan baru dilanjutkan dengan uji reliabilitas. Uji ini bertujuan untuk mengetahui konsistensi kuesioner pada sebuah penelitian. Dinyatakan reliabel apabila nilai cronbach's alpha $>0,60$.

Tabel 3 Kesimpulan Uji Validitas

\begin{tabular}{|c|c|c|c|c|}
\hline Variabel & $\begin{array}{l}\text { Kode } \\
\text { Item }\end{array}$ & $\begin{array}{c}r \\
\text { tabel }\end{array}$ & $\begin{array}{c}\mathbf{r} \\
\text { hitung }\end{array}$ & Ket \\
\hline \multirow{7}{*}{$\begin{array}{c}\text { Perilaku } \\
\text { Penumpang }\end{array}$} & PP1 & 0,195 & 0,717 & Valid \\
\hline & PP2 & 0,195 & 0,629 & Valid \\
\hline & PP3 & 0,195 & 0,597 & Valid \\
\hline & PP4 & 0,195 & 0,574 & Valid \\
\hline & PP5 & 0,195 & 0,589 & Valid \\
\hline & PP6 & 0,195 & 0,551 & Valid \\
\hline & PP7 & 0,195 & 0,550 & Valid \\
\hline \multirow{12}{*}{$\begin{array}{l}\text { Masa } \\
\text { Pandemi }\end{array}$} & MP1 & 0,195 & 0,761 & Valid \\
\hline & MP2 & 0,195 & 0,752 & Valid \\
\hline & MP3 & 0,195 & 0,716 & Valid \\
\hline & MP4 & 0,195 & 0,272 & Valid \\
\hline & MP5 & 0,195 & 0,774 & Valid \\
\hline & MP6 & 0,195 & 0,723 & Valid \\
\hline & MP7 & 0,195 & 0,836 & Valid \\
\hline & MP8 & 0,195 & 0,787 & Valid \\
\hline & MP9 & 0,195 & 0,556 & Valid \\
\hline & MP10 & 0,195 & 0,574 & Valid \\
\hline & MP11 & 0,195 & 0,776 & Valid \\
\hline & MP12 & 0,195 & 0,737 & Valid \\
\hline \multirow{5}{*}{$\begin{array}{c}\text { Pola } \\
\text { Perjalanan }\end{array}$} & PJ1 & 0,195 & 0,656 & Valid \\
\hline & PJ2 & 0,195 & 0,701 & Valid \\
\hline & PJ3 & 0,195 & 0,722 & Valid \\
\hline & PJ4 & 0,195 & 0,596 & Valid \\
\hline & PJ5 & 0,195 & 0,575 & Valid \\
\hline
\end{tabular}

Pada tabel 3 tersebut diketahui setiap butir butir pernyataan yang diisi oleh responden menunjukkan bahwa $r$ hitung $>r$ tabel.

Pada tabel 4 dapat diketahui bahwa semua variabel pada penelitian ini secara umum dinyatakan reliabel (konsisten) karena masing masing variabel memiliki nilai cronbach's alpha> 0,60.

Tabel 4 Kesimpulan Uji Reliabelitas

\begin{tabular}{|c|c|c|c|}
\hline Variabel & $\begin{array}{c}\text { Rentang Nilai } \\
\text { Cronbach's } \\
\text { Alpha }\end{array}$ & $\begin{array}{c}\mathbf{r} \\
\text { hitung }\end{array}$ & Keterangan \\
\hline
\end{tabular}




\begin{tabular}{|l|c|c|c|}
\hline $\begin{array}{l}\text { Perilaku } \\
\text { penumpang }\end{array}$ & 0,60 & 0,612 & Reliabel \\
\hline $\begin{array}{l}\text { Masa } \\
\text { Pandemi }\end{array}$ & 0,60 & 0,874 & Reliabel \\
\hline $\begin{array}{l}\text { Pola } \\
\text { Perjalanan }\end{array}$ & 0,60 & 0,643 & Reliabel \\
\hline
\end{tabular}

\section{B. Uji Asumsi Klasik \\ Uji Normalitas}

Dikatakan sebagai model regresi yang baik apabila memiliki nilai residual distribusi normal yaitu jika nilai signifikansi $>0,05$.

Tabel 4.15 Hasil uji normalitas

One-Sample Kolmogorov-Smirnov

Test

\begin{tabular}{|ll|r|}
\hline & & $\begin{array}{c}\text { Unstandardized } \\
\text { Residual }\end{array}$ \\
\hline $\mathrm{N}$ & Mean & 29 \\
Normal & 0 \\
Parameters $^{a}$ & Std. \\
& Deviation & 1.51377809 \\
Most Extreme & Absolute & 0.134 \\
Differences & Positive & 0.099 \\
& Negative & -0.134 \\
Test Statistic & & 0.134 \\
$\begin{array}{l}\text { Asymp. Sig. (2- } \\
\text { tailed) }\end{array}$ & & $.196 \mathrm{c}$ \\
\hline Test distribution is Normal. & \\
\hline
\end{tabular}

Sumber: Hasil olah data SPSS, 2021

nilai signifikansi sebesar 0,196 yang artinya nilai signifikansi $>0,05$. Sehingga dapat disimpulkan hasil uji normalitas pada penelitian ini dinyatakan normal.

\section{Uji Multikolonieritas}

Untuk mengetahui ada tidaknya masalah multikolonieritas pada variabel penelitian ini dapat dilihat dari nilai VIF (variance inflating factor) dan nilai tolerance nya, apabila VIF kurang dari 10 (VIF < 10), dan memilki nilai tolerance lebih dari 0,1 (tolerance $>0,1$ ) maka tidak terjadi gejala multikolonieritas.

Hasil yang diperoleh dari data yang diisi responden penelitian ini kemudian telah diolah melalui SPSS yaitu nilai VIF sebesar 1,371 yang artinya VIF kurang dari $10(\mathrm{VIF}<10)$ dan nilai tolerance yang diperoleh pada masing masing variabel independen sebesar 0,729 yang artinya nilai tolerance lebih besar dari 0,1 (tolerance $>0,1)$.

\section{Uji Heteroskedastisitas}

Model regresi yang baik adalah yang tidak terjadi heteroskedastisitas. dinyatakan signifikan apabila nilai signifikansinya lebih besar dari tingkat kepercayaan 5\% (sig > 0,05). Pada penelitian ini diperoleh hasil bahwa masing - masing variabel independen memiliki nilai signifikansi diatas 0,05 . Variabel perilaku penumpang sebesar $0,358(0,358>0,05)$ dan variabel masa pandemi sebesar 0,582 $(0,582>$ $0,05)$.

\section{Analisis Regresi Linear Berganda}

Analisis ini dilakukan untuk mengetahui seberapa besar pengaruh antara kedua variabel yakni perilaku penumpang dan masa pandemi terhadap variabel dependen pola perjalanan.

\section{Uji T (Parsial)}

Syarat uji t adalah thitung $>t$ tabel. Perhitungan hipotesis $1(\mathrm{H} 1)$ yang diperoleh melalui SPSS uji t pada penelitian ini yaitu $t$ hitung sebesar 1,280 dan $t$ tabel 1,985. Sehingga dapat disimpulkan bahwa perilaku penumpang tidak berpengaruh terhadap pola perjalanan. Sedangkan nilai $\mathrm{t}$ hitung diketahui 4,309. Sehingga dapat disimpulkan bahwa nilai $\mathrm{t}$ hitung $(4,309)>\mathrm{t}$ tabel $(1,985)$ yang artinya hipotesis kedua (H2) diterima atau masa pandemi berpengaruh terhadap pola perjalanan penumpang.

\section{Uji F (Simultan)}

Uji $F$ dilakukan untuk mengetahui pengaruh pada variabel independen terhadap variabel dependen secara simultan atau bersama - sama. jika nilai signifikan $<0,05$ maka secara simultan kedua variabel independen mempunyai pengaruh terhadap variabel dependen. Pada penelitian ini diperoleh hasil signifikan 0.000 dan Dan nilai f hitung $(17,787)$ $>\mathrm{f}$ tabel $(3,09)$. Sehingga dapat simpulkan bahwa H3 diterima atau terdapat pengaruh secara simultan antara variabel independen dengan variabel dependen.

\section{Uji Koefisien Determinasi}

Pada penelitian ini diperoleh nilai $\mathrm{R}$ square sebesar 0,251. Angka tersebut mengandung arti bahwa perilaku penumpang dan pendemi secara simultan berpengaruh terhadap pola perjalanan sebesar $25,1 \%$.

\section{SIMPULAN}

a. Secara parsial perilaku penumpang tidak berpengaruh pada pola perjalanan 
penumpang KRL. Hal ini dikarenakan perilaku yang diterapkan oleh penumpang selama perjalanan di dalam KRL dianggap sebagai suatu hal yang sudah semestinya dilakukan penumpang guna untuk melindungi diri dari paparan virus covid-19. Namun, perilaku penumpang dapat memberikan pengaruh pada pola perjalanan secara menyeluruh (simultan). Hal ini dikarenakan ketika kebijakan yang diberlakukan semakin diperketat dan penumpang di dalam KRL mematuhi kebijakan serta menerapkan protokol kesehatan maka keamanan dan kenyamanan yang dirasakan pengguna KRL semakin meningkat.

b. Berdasarkan hasil penelitian serta pengujian yang telah dilakukan, secara signifikan pandemi ditinjau dari kebijakan dan pengawasan memberikan pengaruh positif pada pola perjalanan penumpang. Sehingga dapat disimpulkan bahwa semakin ditingkatkannya kebijakan dan pengawasan yang diterapkan selama pandemi maka semakin meningkat pula pola perjalanan yang ditanjau dari rasa aman dan nyaman yang dirasakan penumpang.

\section{UCAPAN TERIMAKASIH}

Dalam penyusunan skripsi ini tidak terlepas dari dukungan berbagai pihak. Peneliti secara khusus mengucapkan terimakasih yang sebesarbesarnya kepada kedua orang tua saya Bapak Kasto dan mendiang (almh) Ibu Marni yang telah memberikan kasih sayang, doa, perhatian serta dukungan dari segi materi maupun moril selama masa kuliah hingga selesainya penyusunan skripsi ini. Kepada Bapak Dr. Sodikin, ST.,MT. selaku dosen pembimbing pertama dan Ibu Tantin Pristyawati, ST.,MT. selaku dosen pembimbing kedua, terimakasih atas segala bimbingan dan bantuannya selama penyusunan skripsi ini. Kepada Bapak Hendramawat Aski Safarizky, S.T.,M.T. selaku dosen penguji yang telah memberikan masukan serta bimbingan selama proses ujian pendadaran berlangsung. Segenap dosen pengajar serta staff karyawan Program Studi Teknik Sipil Universitas Veteran Bangun Nusantara Sukoharjo.

\section{DAFTAR PUSTAKA}

Andriansyah. (2015). Manajemen Transportasi Dalam Kajian dan Teori. Fakultas Ilmu Sosial dan IlmuPolitik Universitas Dr. Moestopo Beragama.
Fay, D. L. (1967). Pengaruh Kompensasi dan Motivasi Terhadap kinerja Pegawai di Kantor Pelayanan Kekayaan dan Lelang bandung. Angewandte Chemie International Edition, 6(11), 951-952., 62-76.

Fitria. (2013). Hubungan karakteristik sosial ekonomi dengan jarak perjalanan yang sesuai dari Kota Cimahi menuju Kota Bandung yaitu. Journal of Chemical Information and Modeling, 53(9), 1689-1699.

Janna, N. M. (2020). Konsep Uji Validitas dan Reliabilitas dengan Menggunakan SPSS. Artikel: Sekolah Tinggi Agama Islam (STAI) Darul Dakwah Wal-Irsyad (DDI) Kota Makassar, 18210047, 1-13.

Lestari, I., \& Hamid, R. S. (2020). Analisis Tingkat Kepercayaan Dan Kepuasan Pelanggan Terhadap Niat Untuk Menggunakan Kembali Layanan Transportasi Online Di Era Pandemi Covid-19. Equilibrium: Jurnal Ilmiah Ekonomi, Manajemen Dan Akuntansi, 9(1), 27-35.

https://doi.org/10.35906/je001.v9i1.482

Lois, Y. W., Linggasari, D., \& Angkat, H. (2021). Analisis Perilaku Penumpang Krl Bogor Jakarta Kota Pada Masa Pandemi. Jurnal Mitra Teknik Sipil, 4(1), 11. https://journal.untar.ac.id/index.php/jmts/artic le/view/10464/6940

Pamungkas, W. G., Rahmawati, D., Anggraini, L., Sipil, T., Teknik, F., Semarang, U., Hatta, J. S., Kulon, T., \& Tengah, J. (n.d.). Analisa Perilaku Pengguna Angkutan Umum Penumpang Antarmoda Kereta Api Kaligung Semarang-Tegal. 1-7.

Pemerintahan, P. I. (2019). Pengertian Kebijakan Pemerintahan. 1-16.

Pranata, S. (2010). Hubungan Aromaterapi Minyak Rosmarini terhadap Ketelitian dan Kewaspadaan. 1(18), 2002-2003.

Raharjo, S. (2019). Trik Analisis Regresi Linear Berganda Sekaligus Uji Asumsi Klasik dengan SPSS. X. http://youtu.be/CUDi5BFQO10

Saekoko, A. N., Nyoko, A. E. L., \& Fanggidae, R. P. C. (2020). Analisis Faktor-Faktor Yang Mempengaruhi Perilaku Konsumen Dalam Pembelian Smartphone Xiaomi (Studi Kasus Pada Mahasiswa Pengguna Smartphone Xiaomi Di Universitas Nusa Cendana). Journal of Management: Small and Medium Enterprises (SMEs), 11(1), 49-64. https://doi.org/10.35508/jom.v11i1.2318 
sugiyono. (2012). Pengaruh Kualitas Pelayanan Pajak Kendaraan Bermotor Terhadap Kepatuhan Wajib Pajak Kendaraan Bermotor. Akutansi, 56-85.

Tanzeh, A., \& Arikunto, S. (2014). Metode Penelitian Metode Penelitian. Metode Penelitian, 22-34.

v. M. buyanov. (1967). Pengaruh Variabel Harga, kualitas produk dan prmosi terhadap keputusan pembelian teh siap minum dalam kemasan merk "Teh Botol sosro" (Studi pada tempat makan bakso kikil siberut indah ponorogo). Angewandte Chemie International Edition, 6(11), 951-952., 1-16.

Widiarta, I. B. P. (2010). Analisis Pemilihan Moda Untuk Perjalanan Kerja ( Studi Kasus : Desa Dalung, Kecamatan Kuta Utara, Badung, Bali ). Jurnal Ilmiah Teknik Sipil, 14(2), 218-225.

Yanti, N. P. E. D., Nugraha, I. M. A. D. P., Wisnawa, G. A., Agustina, N. P. D., \& Diantari, N. P. A. (2020). Gambaran Pengetahuan Masyarakat Tentang Covid-19 Dan Perilaku Masyarakat Di Masa Pandemi Covid-19. Jurnal Keperawatan Jiwa, 8(4), 491. 